\title{
アルミニウム基合金における応力一 ひずみ曲線の評価
}

\author{
上谷 保裕* ·浅井 吉夫** \\ 池野進 ${ }^{* *} \cdot$ 多々 静夫***
}

An evaluation of stress-strain curves in Al-base alloys

\author{
Yasuhiro UETANI*, Yoshio ASAI** \\ Susumu IKENO*** and Shizuo TADA***
}

\begin{abstract}
Tensile tests have been carried out at room and low temperatures in order to examine the applicabilities of Hollomon equation $\sigma=K_{H} \varepsilon^{n_{H}}$ and Ludwik equation $\sigma=\sigma_{0}+K_{L} \varepsilon^{n_{L}}$ to the stress-strain curves of Al-Mg, Al-Cu and Al$\mathrm{Zn}$ alloys. Hollomon equation does not hold in each alloy, and the higher the solute concentration, the larger the deviation from the linearity on log-log plots. On the other hand, Ludwik equation agrees well with the observed stress-strain relationship in low strain ranges where values of $n_{L}$ are approximately equal to those calculated from the slopes of log-log plots of $d \sigma / d \varepsilon$ and strain. The amount of strain to maximum load which is predicted from Ludwik equation in higher strain ranges is fairly close to the observed one.
\end{abstract}

Keywords: Hollomon equation, Ludwik equation, strain at the maximum load, stress-strain curves, Al-base alloys

(Received August 19, 1985)

\section{1. 緒言}

これまで，アルミニウム基合金においては実験的な加 工硬化式として Hollomon 式'功頻繁に用いられてい $3^{2) \sim 8)}$ 。の Hollomon 式以外にも著名な実験式はいく つか挙げられる年〜11) が，Hollomon 式は他の式に比べて その形が単純であり，応力とひずみの両対数プロットの 直線近似により容易に各定数が求められること。さらに 定数 $n_{H}$ が最大荷重点までの伸びとかなりよい関係があ ること ${ }^{12), 13)}$ 等もこの式が多用される要因であろう。

しかし, Hollomon式では応力一ひずみ曲線のひずみ 初期の領域を近似できないこと故が良く知られており， 実際には低ひずみ領域を無視して 5〜10\%以上のひずみ 域で直線近似がなされるのが一般的である ${ }^{6), 71}$ 。また Ratke ら ${ }^{15)}$ は種々の合金における応力一ひずみ曲線を微 小ひずみ領域で解析し，Hollomon 式が特に実測值との ずれが大きく，純アルミニウムやアルミニウム合金にお いても適用できないのではないかと述べている。従つて,
Hollomon 式がアルミニウム基合金に適用されうるかど うかを再検討する必要があると思われる。

そこで，本研究ではまずアルミニウム基合金において Hollomon 近似する場合にどのような問題点があるのか を調べた。また，Hollomon 式の検討結果から，応力一 ひずみ曲線は Ludwik 式9)を用いればより良く近似する ことになると予想されたが，Ludwik 式を用いてアルミ ニウム基合金の応力一ひずみ曲線を詳細に調べた報告は ほとんど無く ${ }^{16)}$ ，アルミニウム中の溶質濃度の影響など 不明の点が多い。そこで, $\mathrm{Al}-\mathrm{Mg}, \mathrm{Al}-\mathrm{Cu}, \mathrm{Al}-\mathrm{Zn}$ 合金 を用いて検討した結果についても報告する。

\section{2. 実 験方法}

純度99.99\%のアルミニウムと亜鉛，99.9\%のマグネ シウムならびに $\mathrm{Al}-33 \% \mathrm{Cu}$ 母合金の各鋳塊を使用して 大気中溶解により，純アルミニウム，Al-0.5, 1, 3, 5\% $\mathrm{Mg}$ 合金， $\mathrm{Al}-0.5,1,2,4 \% \mathrm{Cu}$ 合金および $\mathrm{Al}-1,2,4 \%$ $\mathrm{Zn}$ 合金の各合金を鋳造した。各合金の化学組成を

* 富山県立技術短期大学 (射水郡)。Toyama Prefectural College of Technology.

** 富山大学大学院 (富山市) (現, 武内プレス工業(侏))。Graduate School, Toyama University (Toyoma).

*** 富山大学工学部 (富山市)。Faculty of Engineering, Toyama University (Toyama). 
Table 1 Analysis of specimens (wt $\%$ )

\begin{tabular}{l|c|c|c|c}
\hline \hline alloys & $\mathrm{Mg}$ & $\mathrm{Cu}$ & $\mathrm{Zn}$ & $\mathrm{Al}$ \\
\hline $0.5 \% \mathrm{Mg}$ & 0.46 & - & - & $\mathrm{bal}$. \\
$1 \% \mathrm{Mg}$ & 1.04 & - & - & bal. \\
$3 \% \mathrm{Mg}$ & 3.06 & - & - & bal. \\
$5 \% \mathrm{Mg}$ & 4.96 & - & - & bal. \\
$0.5 \% \mathrm{Cu}$ & - & 0.37 & - & bal. \\
$1 \% \mathrm{Cu}$ & - & 0.92 & - & bal. \\
$2 \% \mathrm{Cu}$ & - & 1.80 & - & bal. \\
$4 \% \mathrm{Cu}$ & - & 3.96 & - & bal. \\
$1 \% \mathrm{Zn}$ & - & - & 0.70 & bal. \\
$2 \% \mathrm{Zn}$ & - & - & 2.00 & bal. \\
$4 \% \mathrm{Zn}$ & - & - & 3.60 & bal. \\
\hline
\end{tabular}

Table 1 に示す。これらを厚さ $10 \mathrm{~mm}$ まで熱間圧延後， 冷間圧延により厚さ $1 \mathrm{~mm}$ の板材とし, 平行部長さ $18.5 \mathrm{~mm}$ (標点間長さ $18 \mathrm{~mm}$ ), 幅 $6 \mathrm{~mm}$, 厚さ $0.9 \mathrm{~mm}$ の試験片形状に仕上げた。結晶粒度調整は塩浴中で行 い, 所定の温度で $30 \mathrm{~min}$ 保持後, 水冷した。平均結晶 粒径は $\mathrm{Al}-\mathrm{Mg}$ 合金では主に $45 \mu \mathrm{m}$ とした。一方， $\mathrm{Al}-$ $\mathrm{Cu}$ 合金では $4 \% \mathrm{Cu}$ 合金の溶体化処理温度が高温とな り, 平均結晶粒径が $150 \mu \mathrm{m}$ となつたので, 他の濃度の 合金も $4 \% \mathrm{Cu}$ 合金と合わせて $150 \mu \mathrm{m}$ に粒径調整した。 $\mathrm{Al}-\mathrm{Zn}$ 合金においても, やはり，4\% Zn 合金に溶体化 処理が必要であつたため結晶粒径を $150 \mu \mathrm{m}$ に調整し た。

引張試験はインストロン型の試験機（島津製 DSS5000）を使用し, 室温と液体窒素中において, 初期ひず み速度 $9.26 \times 10^{-4} / \mathrm{sec}$ にて行つた。この場合, 荷重一 時間曲線の記録は $\mathrm{X}-\mathrm{t}$ 計録計の他に試験機に直結した A/D コンバータを介してパソコン（YHP 製 HP-85）に よつても計測記録した。このときの荷重の計測誤差は各 荷重の值に対して平均約 $0.5 \%$ 以内であつた。

本実験では引張チャートから真応力を $\sigma=S(1+e)$, 真ひずみを $\varepsilon=\ln (1+e)(S$ は公称応力, $e$ は公称ひず み）で計算した值を用いて㐫力一ひずみ曲線を解析した 結果について報告する。また，あらかじめ $3 \mathrm{~mm}$ 間隔で 試験片表面にけがき線を入れ，引張り変形中の試験片を 写真撮影して各場所の变形量を測定したところ，標点間 内では最大荷重を過ぎるころで局部収縮が始まるころに は変形量の局部的増大が認められたが，それまではほぼ 均一に変形していた。なお，本実験においては真応力， 真ひずみを応力，ひずみと呼び，最大荷重までのひずみ 領域での真応力一真ひずみ曲線を応力一ひずみ曲線と称 する。

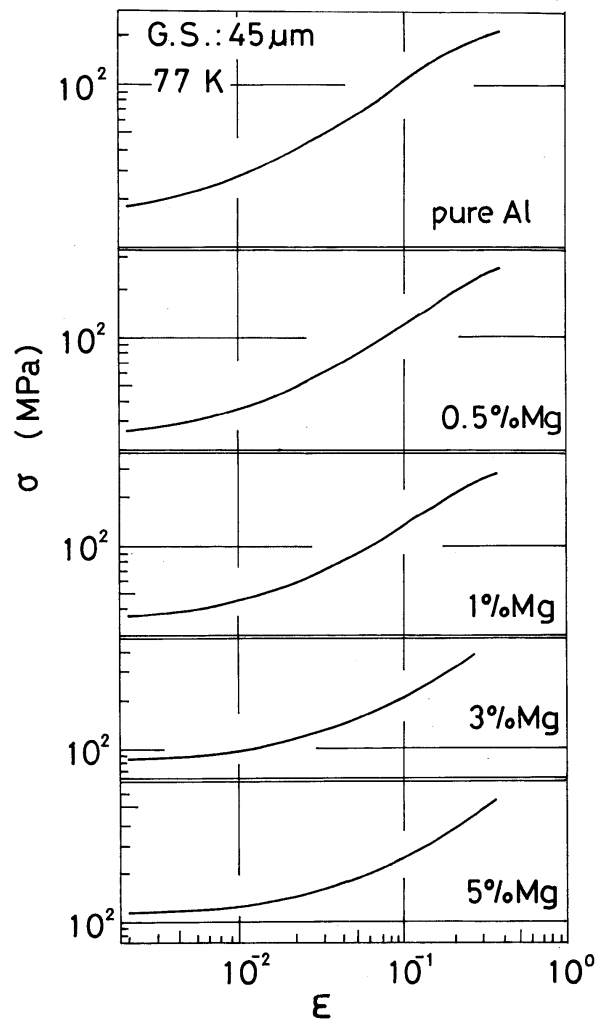

Fig. 1 Plots of $\log \sigma$ against $\log \varepsilon$ in pure $\mathrm{Al}$ and $\mathrm{Al}-$ $\mathrm{Mg}$ alloys deformed at $77 \mathrm{~K}$. The curves were obtained by employing Hollomon equation ${ }^{1)}$. $\sigma$ : stress, $\varepsilon$ : strain

\section{3. 実験結果および考察}

\subsection{Hollomon 式の検討}

Fig. 1 は Hollomon 式

$$
\sigma=K_{H} \varepsilon^{n_{H}}
$$

(ここで $\sigma$ は応力， $\varepsilon$ はひずみ， $K_{H}$ と $n_{H}$ は定数）を用 いて, $\mathrm{Al}-\mathrm{Mg}$ 合金の応力一ひずみ曲線を両対数プロッ トした結果である。図は液体窒素中における変形の場合 であるが，図から分かるように純アルミニウム試料にお いてさえ，このプロットでは応力とひずみの関係が曲線 のように見られ直線近似が困難である。また，マグネシ ウム濃度が増すと, 明らかに両者の関係は曲線を描いて いる。このような傾向はいずれの合金系においても，ま た室温変形の場合でも同様であつた。

今，仮に応力とひずみの関係が Hollomon 式で表され るならば，Fig. 2(a)に図式的に示すような曲線となる。 ここで注意すべき点は $\varepsilon=0$ の時, $\sigma=0$ であることであ る。しかし，実際の金属，合金の応力一ひずみ曲線にお いては同図(b)に示すように $\varepsilon=0$ の時に $\sigma=A$ という降 
(a)

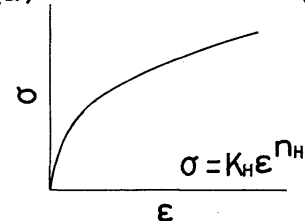

(b)

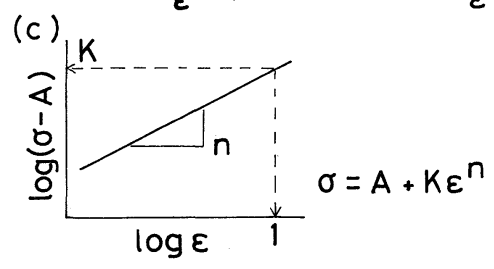

Fig. 2 Schematic illustrations of $\sigma-\varepsilon$ curve.

(a) theoretical $\sigma-\varepsilon$ curve according to Hollomon equation. (b) experimental $\sigma-\varepsilon$ curve. (c) a plot of $\log (\sigma-\mathrm{A})$ against $\log \varepsilon$ according to equation (2) which corresponds to Ludwik equation ${ }^{2}$. The plot gives a straight line.

伏あるいは比例限に相当する応力值が存在する。そこで, Fig. 3 に

$$
\sigma=A+K \varepsilon^{n}
$$

として, 定数 $A, K$ および $n$ をいろいろ変えて $\sigma$ と $\varepsilon$ の 両対数プロットを行つた結果を示す。Fig. 3(a) におい ては $K$ と $n$ はそれぞれ一定である。図から分かるよう に, $A=0$ の場合は直線となるが， $A>0$ の場合は曲線と なり，Aの值が大きいほどその曲率は大きくなることが 分かる。従つて，実際の金属および合金では塑性変形開 始に要する応力 $(\mathrm{A})$ が存在するので応力一ひずみ曲線を Hollomon 式を用いて両対数プロットすると必ず曲線と なることになる。こうした曲線の曲率におよぼす影響は $A$ のみではなく, 他の定数にもある。Fig. 3(b) $K$ と $A$ が一定の場合に $n$ の值の影響を見たものである。この 場合には $n$ の值が大きいと曲率が大きくなり, $n=1$ で 最も大きくなる。

さて，Hollomon 式を用いて応力一ひずみ曲線を両対 数プロットした場合にひずみ量とともに応力が曲率をも つて上昇する現象は Pysz ら ${ }^{17}$ によつて $\mathrm{Cu}-\mathrm{Zn}$ 合金にお いても報告されている。彼らはこの現象をDouble-n 現 象として取り扱つているが，上述のように，Hollomon 式を用いると実際の応力一ひずみ曲線とは異なつてしま らので，そうした現象を取り扱う時には厳密な検討と整 理上での見直しが必要であろう。

\subsection{Ludwik 式による応力一ひずみ曲線の検討}

\subsubsection{Ludwik 式の適用できるひずみ範囲}

今，仮にアルミニウム基合金において，(2)式で示し た関係が成立つならば，Fig. 2(c)で見るように $(\sigma-A)$ と $\varepsilon$ の両対数プロットは直線となる。ここで，(2)式は

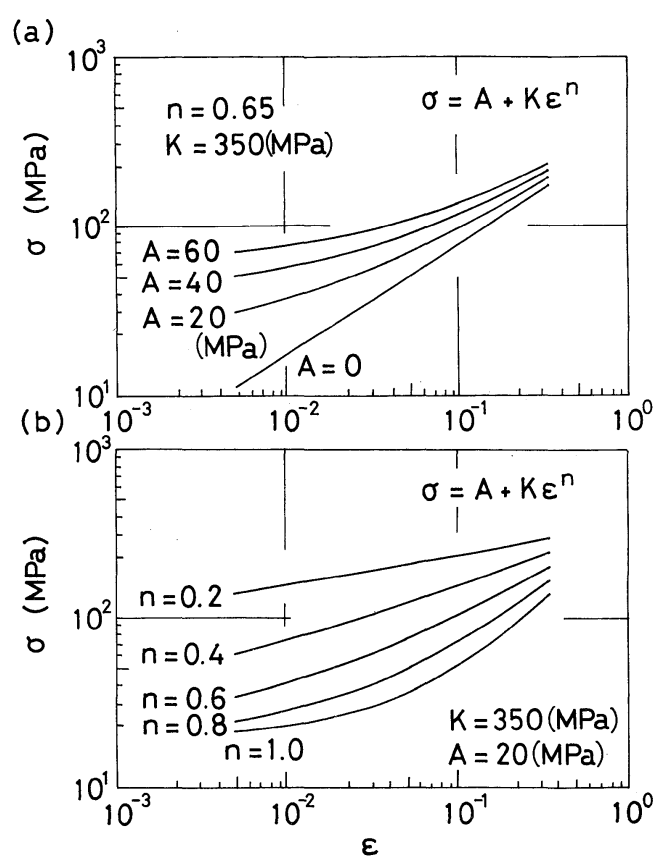

Fig. 3 Plots of $\log \sigma$ against $\log \varepsilon$ according to Hollomon equation (schematic illustrations).

(a) varying $A,(b)$ varying $n$.

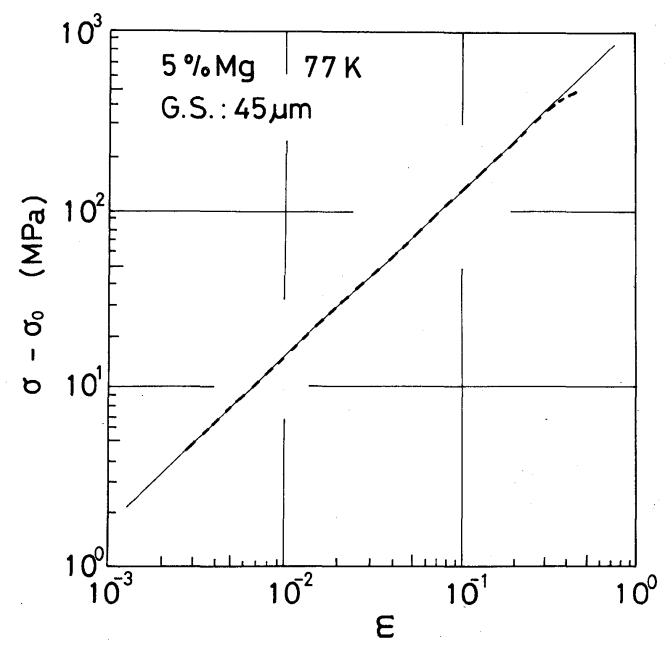

Fig. 4 Plot of $\log \left(\boldsymbol{\sigma}-\boldsymbol{\sigma}_{0}\right)$ against $\log \boldsymbol{\varepsilon}$ according to Ludwik equation in $\mathrm{Al}-5 \% \mathrm{Mg}$ alloy deformed at $77 \mathrm{~K}$.

----: experimental, ——: Ludwik equation.

$$
\sigma=\sigma_{0}+K_{L} \varepsilon^{n_{L}}
$$

$\left(\sigma_{0}, K_{L}, n_{L}\right.$ は定数）と表現でき，この式はその形だけ でみると，すでに Ludwik が提唱した ${ }^{9)}$ もと同じとな る。そこで，以下ではこの形の式を Ludwik 式と呼ぶ。 今, (3)式が $\mathrm{Al}-5 \% \mathrm{Mg}$ 合金の液体窒素中の変形の場合 


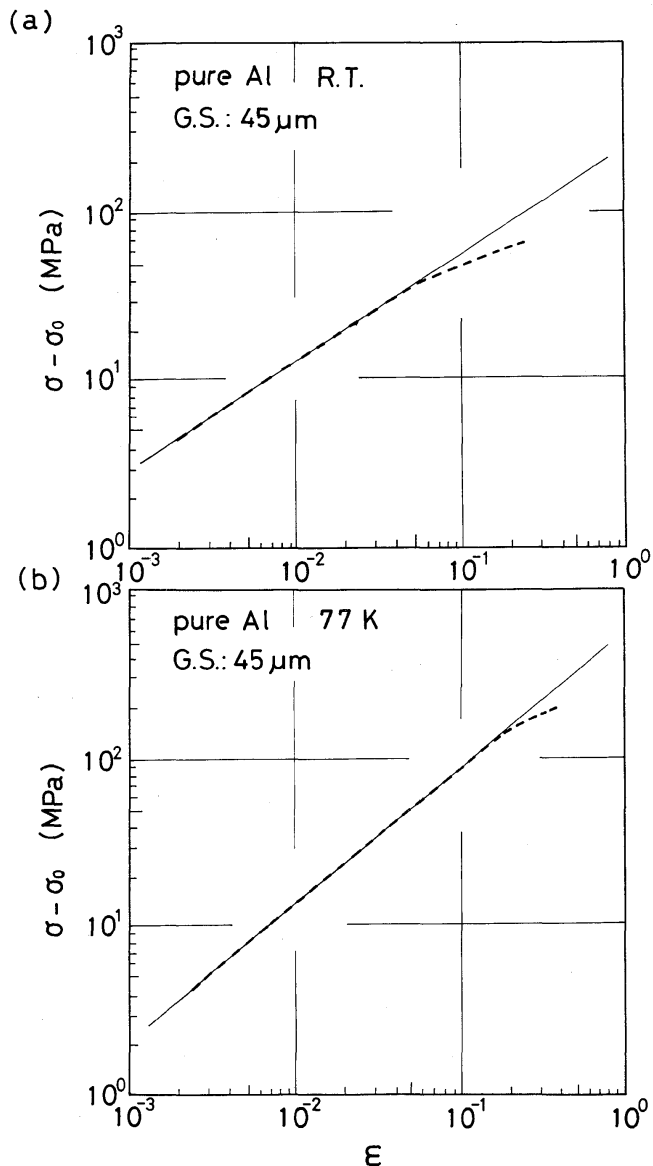

Fig. 5 Plots of $\log \left(\sigma-\sigma_{0}\right)$ against $\log \varepsilon$ according to Ludwik equation in pure Al. ----: experimental, - Ludwik equation.

(a) deformed at room temperature

(b) deformed at $77 \mathrm{~K}$.

について適用できるかどうかを調べた結果を Fig. 4 に 示す。ここで, この場合の $\sigma_{0}$ はコンピュータによる回 帰から比例限と想定された值を用いた。この図から, $\mathrm{Al}-5 \% \mathrm{Mg}$ 合金では Ludwik 式による近似が低ひずみ領 域でかなり良く合つていることが分かる。しかし，高ひ ずみ領域でこの低ひずみ領域の近似線の外插から外れ下 回つている。このようなずれはFig. 5(a)に示すように 純アルミニウムにおいて一層顥著であり, 比較的に低い ひずみ域から生じている。他の合金系においても Fig. 4, 5 と同様な結果が得られ，Ludwik 式によつては，応 力一ひずみ曲線全体を近似できなかつた。しかし，低ひ ずみ領域ではかなり良い近似がいずれの合金においても 可能であつた。

ひずみ量が増すと低ひずみ領域の近似線の外挿から外 れるのは，実際の応力が外挿線の近似值よりも低いこと

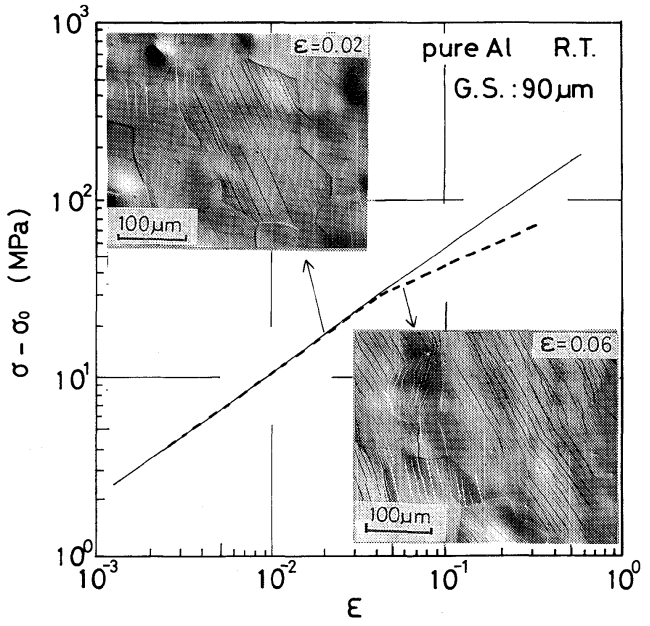

Fig. 6 Plot of $\log \left(\sigma-\sigma_{0}\right)$ against $\log \varepsilon$ and slip bands of specimen surface in pure $\mathrm{Al}$ deformed at room temperature. The specimen had a grain size of 90 $\mu \mathrm{m}$.
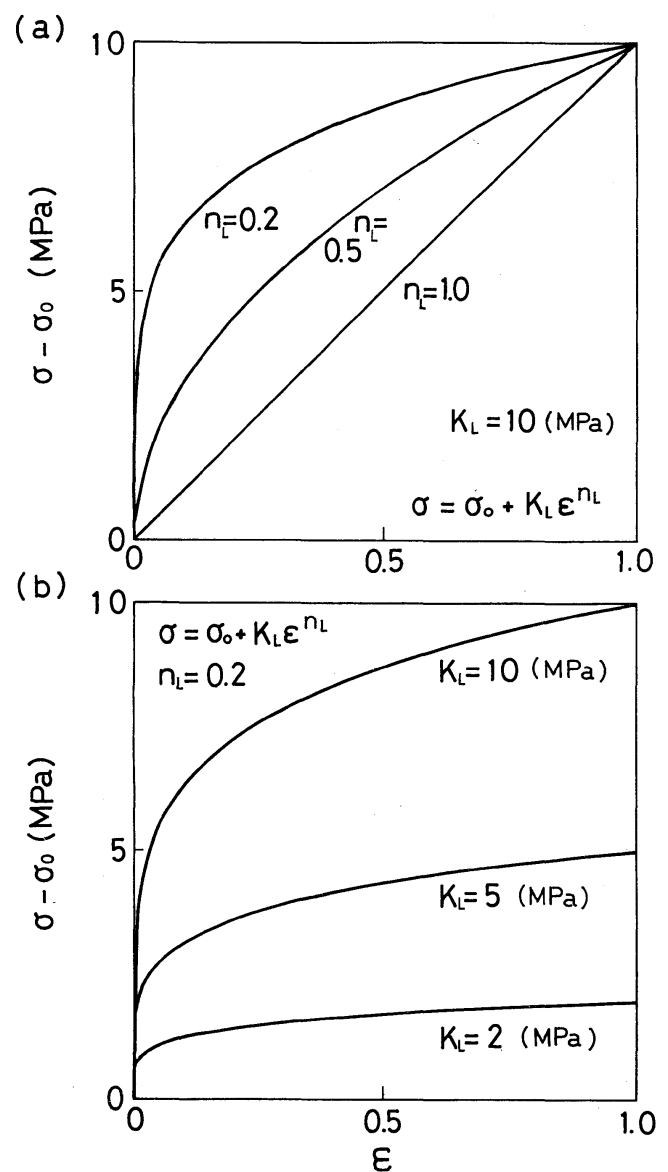

Fig. 7 Schematic $\left(\sigma-\sigma_{0}\right)-\varepsilon$ curves according to Ludwik equation

(a) varying $n_{L}$, (b) varying $K_{L}$. 
Table $2 \sigma_{0}, K_{L}$ and $n_{L}$ (obtained by the use of Ludwik equation) at lower strains in various Al-base alloys

\begin{tabular}{l|c|c|c|c|c|c}
\hline \multirow{2}{*}{ alloys } & \multicolumn{5}{|c}{ deformation temperature } \\
\cline { 2 - 7 } & \multicolumn{2}{|c|}{ room temperature } & \multicolumn{3}{|c}{$77 \mathrm{~K}$} \\
\hline & $\begin{array}{c}\sigma_{0} \\
(\mathrm{MPa})\end{array}$ & $\begin{array}{c}K_{L} \\
(\mathrm{MPa})\end{array}$ & $n_{L}$ & $\sigma_{0}$ & $K_{L}$ & $\left.n_{L}\right)$ \\
$(\mathrm{MPa})$ & $n_{L}$ \\
\hline pure $\mathrm{Al}^{*}$ & 7.0 & 230 & 0.64 & 14.7 & 574 & 0.81 \\
$0.5 \% \mathrm{Mg}^{*}$ & 13.0 & 299 & 0.63 & 23.2 & 596 & 0.82 \\
$1 \% \mathrm{Mg}^{*}$ & 20.0 & 350 & 0.64 & 33.0 & 630 & 0.83 \\
$3 \% \mathrm{Mg}^{*}$ & 71.0 & 715 & 0.81 & 85.3 & 1015 & 0.94 \\
$5 \% \mathrm{Mg}^{*}$ & 110.0 & 835 & 0.83 & 116.0 & 1165 & 0.94 \\
pure Al** & 6.6 & 264 & 0.74 & 12.7 & 534 & 0.85 \\
$0.5 \% \mathrm{Cu}^{* *}$ & 15.0 & 305 & 0.74 & 12.7 & 534 & 0.85 \\
$1 \% \mathrm{Cu}^{* *}$ & 19.2 & 391 & 0.73 & 23.5 & 563 & 0.83 \\
$2 \% \mathrm{Cu}^{* *}$ & 34.0 & 543 & 0.76 & 49.8 & 723 & 0.82 \\
$4 \% \mathrm{Cu}^{* *}$ & 110.0 & 667 & 0.71 & 110.0 & 806 & 0.74 \\
$1 \% \mathrm{Zn}^{* *}$ & 8.2 & 337 & 0.77 & 15.4 & 518 & 0.88 \\
$2 \% \mathrm{Zn}^{* *}$ & 10.2 & 320 & 0.76 & 16.9 & 529 & 0.85 \\
$4 \% \mathrm{Zn}^{* *}$ & 16.1 & 328 & 0.71 & 44.0 & 440 & 0.67 \\
\hline
\end{tabular}

*: grain size $45 \mu \mathrm{m}$.

**: grain size $150 \mu \mathrm{m}$.

から，変形が進むとともに動的回復による軟化が激しく なるためと思われる。すなわち，純アルミニウムでは $\mathrm{Al}-5 \% \mathrm{Mg}$ 合金のような高マグネシウム濃度の合金と比 較して交差すべりが発生し易いので, 後者に比べれば前 者の方がセル形成などにより動的回復が生じ易(18),19)。 その結果純アルミニウムの方が軟化が激しくなり，より 低いひずみからずれが始まるのではないかと考えられる。

Fig. 6 には室温変形の場合に直線近似されるひずみ域と ずれ始めて間もないひずみにおいて，試料表面のすべり 模様観察を行つた時の一例を示す。図中の写真は所定の ひずみまで変形した後，生じたすべり帯を一旦除去し， その後さらに $0.5 \%$ のひずみ量を付加した時の組織であ る。写真から分かるように, Ludwik 式による近似が可 能であるひずみ範囲では比較的に直線的なすべり帯が見 られるのに対し，ひずみ量が大きく Ludwik 式の近似線 からそれて応力値が下回る時にはすべり帯が非常に波状 となり，交差すべりが多発していることがうかがえる。 また，一般に交差すべりの難易は熱活性の問題であり， 変形温度と密接に関係する ${ }^{19)}$ ので，低温になれば軟化は しにくくなると予想される。そこで純アルミニウムを液 体窒素中で試験した結果がFig. 5(b)であり，明らかに 室温変形の図 $(\mathrm{a})$ に比べてずれ始めるのが高ひずみ側へ 移行しており, 軟化が生じにくくなつたと推察される。

3.2 .2 低ひずみ領域における Ludwik 式の定数 $K_{L}$ お よび $n_{L}$ の検討
Table 2*に Ludwik 式が適用できる低ひずみ領域での $\sigma_{0}, K_{L}$ と $n_{L}$ の值を示す。 $K_{L}$ および $n_{L}$ は, $\mathrm{Al}-\mathrm{Mg}$ 合金 では室温および夜体窒素中の変形の双方においてマグネ シウム濃度が高くなるとともにいずれも高くなる。従つ て， $\mathrm{Al}-\mathrm{Mg}$ 合金においてはマグネシウム濃度が増すほ ど， $n_{L}$ が大きくなるので応力一ひずみ曲線が直線的に なり，同時に $K_{L}$ も大きくなることから加工硬化量が増 すことになる。一方， $\mathrm{Al}-\mathrm{Cu}$ 合金においては $n_{L}$ はほと んど銅濃度により变化せず， $K_{L}$ が銅濃度とともに大き くなつている。従つて，この場合には応力一ひずみ曲線 の形状が銅濃度の増加とともに変化しているようである が，これは $K_{L}$ の増加により硬化量が大きくなつたため である（Fig. 7 (b)参照)。また, $\mathrm{Al}-\mathrm{Zn}$ 合金の場合は亜 鉛濃度の増加による固溶硬化は見られており，各ひずみ における応力値は亜鉛濃度の増加とともに上昇した。し かし， Table 2 から分かるように亜鉛濃度によつては $K_{L}$, $n_{L}$ ともにほとんど変化していない。従つて, 亜鉛濃度 の増加は加工硬化にはほとんど影響しないと思われる。

さて, Ratke ら ${ }^{15)}$ は実際の応力一ひずみ曲線を両対数 プロットし，また Hollomon, Ludwik 等の加工硬化式を 用いて応力ーひずみ曲線を近似した後, さらに両対数プ ロットした。得られた双方の両対数プロットを再び微小 ひずみ域で解析し，その傾きを求めて比較した。その結 果, 実測された傾きの値と近似曲線から得られた值にあ まり良い一致が認められず，特に Hollomon 式における 結果が不一致の程度が大きいと報告している。また， Adams ら ${ }^{20)}$ は応力一ひずみ曲線を微小ひずみ域で解析 すると，その傾きの值がひずみ量の増加とともに単純な 指数関数に乗つては変化しないことから，応力とひずみ の関係は単一の指数曲線では表せないとしている。この ような微小ひずみ域における解析と $n_{L}$ との関係がどの ようなものであるかを知るために，本実験においても

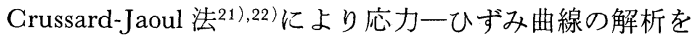
行つた。Fig. 8 は純アルミニウムの液体窒素中での変形 の場合の応力一ひずみ曲線を $\log (d \sigma / d \varepsilon)-\log \varepsilon$ プロッ トした結果である。なお，この場合は $d \varepsilon=\Delta \varepsilon=0.4 \%$ と して硬化率 $(d \sigma / d \varepsilon)$ を計算した。図から分かるように, ひずみ量が約 $0.5 \%$ 以下で硬化率の急激な低下が見られ る。この急激な低下についてはさらに詳細な検討が必要

\footnotetext{
* $\mathrm{Al}-3,5 \% \mathrm{Mg}$ 合金, $\mathrm{Al}-2,4 \% \mathrm{Cu}$ 合金および $\mathrm{Al}-4 \%$ $\mathrm{Zn}$ 合金の室温変形に抢いては荷重一伸び曲線にセ レーションが発生したため, 応力一ひずみ曲線も 実際にはわずかにゆらいでいた。しかし， Hollomon および Ludwik 式による近似を行う場合 には，このゆらぎの程度が小さかつたためか，ほ とんどその影響は見られなかつた。一方，加工硬 化率 $(d \sigma / d \varepsilon)$ はセレーションが生じると測定不可 能であつた。
} 


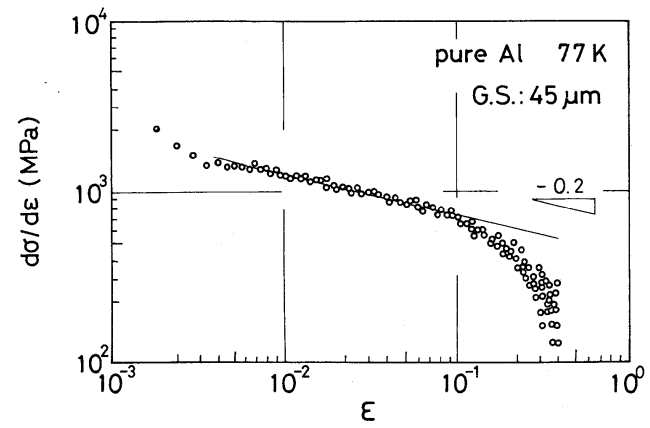

Fig. 8 Plot of $\log (d \sigma / d \varepsilon)$ against $\log \varepsilon$ according to C-J method ${ }^{20), 21)}$ in pure $\mathrm{Al}$ deformed at $77 \mathrm{~K}$. The slope of a straight lines in the figure gives $\left(n_{L}-1\right)$ by equation (5).

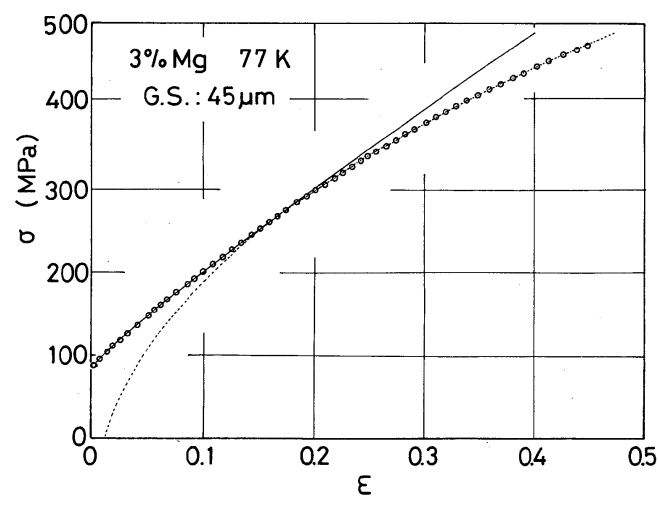

Fig. 9 Approximation of experimental $\boldsymbol{\sigma}-\boldsymbol{\varepsilon}$ curve for $\mathrm{Al}-3 \% \mathrm{Mg}$ alloy deformed at $77 \mathrm{~K}$ by the use of Ludwik equation.

$\cdots$ : experimental data (selected).

- : approximation at lower strains.

----: approximation at higher strains.

であるが，現時点ではよく分からない。今，約 $0.5 \% を$ 超えるとひずみ量の増加に伴い硬化率がほぼ直線的に減 少するひずみ領域が見られる。この直線のこう配から求 めた $n_{L}$ と先に Fig. $5(\mathrm{~b})$ から得られた $n_{L}$ の值が大体一 致していた（Table 2 参照)。ところが，さらにひずみ 量が増すと再び硬化率が急激に低下している。この再び 硬化率が減少し始めるひずみ量は Fig. 5(b)に示した Ludwik 式による近似線から実測值が下回り始めるひず み量とほぼ一致していた。このような結果は各合金によ つても同様であつた。この結果から明らかなように, Ludwik 式を用いて近似を行う場合，全ひずみ領域を無 理に近似してしまえば硬化率の変化とは当然合わなくな る。Ratke らやAdams らは本実験で行つたようにひず み領域を区切つて近似しなかつたため実測值との相違が 生まれたものと思われる。また，当然ながら Hollomon
Table 3 Strain at maximum load in various Al-base alloys

\begin{tabular}{|c|c|c|c|c|c|c|}
\hline \multirow{3}{*}{ alloys } & \multicolumn{6}{|c|}{ deformation temperature } \\
\hline & \multicolumn{3}{|c|}{ room temperature } & \multicolumn{3}{|c|}{$77 \mathrm{~K}$} \\
\hline & $\varepsilon_{\mathrm{m}}$ & $\varepsilon_{\mathrm{mL}}$ & $\varepsilon_{\mathrm{mH}}$ & $\varepsilon_{\mathrm{m}}$ & $\varepsilon_{\mathrm{mL}}$ & $\varepsilon_{\mathrm{mH}}$ \\
\hline pure $\mathrm{Al}^{*}$ & 0.26 & 0.34 & 0.38 & 0.39 & 0.43 & 0.49 \\
\hline $0.5 \% \mathrm{Mg}^{*}$ & 0.24 & 0.31 & 0.33 & 0.41 & 0.48 & 0.58 \\
\hline $1 \% \mathrm{Mg}^{*}$ & 0.24 & 0.31 & 0.34 & 0.40 & 0.47 & 0.56 \\
\hline $3 \% \mathrm{Mg}^{*}$ & 0.24 & 0.35 & 0.41 & 0.45 & 0.54 & 0.58 \\
\hline $5 \% \mathrm{Mg}^{*}$ & 0.26 & 0.37 & 0.41 & 0.45 & 0.51 & 0.61 \\
\hline pure $\mathrm{Al}^{* *}$ & 0.28 & 0.35 & 0.40 & 0.41 & 0.48 & 0.62 \\
\hline $0.5 \% \mathrm{Cu}^{* *}$ & 0.25 & 0.35 & 0.42 & 0.40 & 0.46 & 0.54 \\
\hline $1 \% \mathrm{Cu}^{* *}$ & 0.25 & 0.37 & 0.44 & 0.43 & 0.50 & 0.60 \\
\hline $2 \% \mathrm{Cu}^{* *}$ & 0.24 & 0.34 & 0.41 & 0.38 & 0.46 & 0.55 \\
\hline $4 \% \mathrm{Cu}^{* *}$ & 0.20 & 0.28 & 0.34 & 0.36 & 0.42 & 0.45 \\
\hline $1 \% \mathrm{Zn}^{* *}$ & 0.31 & 0.32 & 0.36 & 0.39 & 0.44 & 0.60 \\
\hline $2 \% \mathrm{Zn}^{* *}$ & 0.30 & 0.34 & 0.38 & 0.39 & 0.46 & 0.60 \\
\hline $4 \% \mathrm{Zn}^{* *}$ & 0.21 & 0.32 & 0.38 & 0.27 & 0.40 & 0.47 \\
\hline $\begin{array}{l}* \text { : grain si } \\
* * \text { : grain si } \\
\varepsilon_{\mathrm{m}}: \text { experim } \\
\varepsilon_{\mathrm{mL}}: \text { calcula } \\
\varepsilon_{\mathrm{mH}}(=\mathrm{nH}\end{array}$ & $45 \mu \mathrm{m}$ & 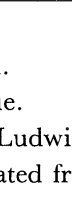 & $\mathrm{n} \mathrm{H}$ & n. & & \\
\hline
\end{tabular}

式を用いた場合は近似曲線自体が変つてしまうので実測 值とは異なるはずである。

さて，ここで Hollomon 式で応力一ひずみ曲線を近似 すると, 変形機構が変化せず無限に材料が変形すれば, Fig. 3(a)から分かるように，いずれは Ludwik 式の持つ 傾き $n_{L} に n_{H}$ が近づくという事実が注目される。このこ とから，ひずみ量の大きな領域では Hollomon 式によつ ても応力一ひずみ曲線が比較的に近似されうる可能性が ある。このことが Hollomon 式により応力一ひずみ曲線 を比較的高ひずみ領域で近似すると，最大荷重点までの ひずみ量と $n_{H}$ の值とに良い関係が得られると報告され ている(2),13) ことの理由ではないかと考えた。そこで, 以下に最大荷重点までのひずみ量と $n_{L}$ および $n_{H}$ との関 係を調べた結果について述べる。

\subsection{Hollomon 式と Ludwik 式による最大荷重点ま でのひずみ量の評価}

最大荷重点までのひずみ量 $\varepsilon_{\mathrm{m}}$ は,

$$
\sigma=d \sigma / d \varepsilon
$$

という条件を用いて計算され, Hollomon 式では $\varepsilon_{\mathrm{m}}=n_{H}$ が導かれる。(4)の持つ意味は $d \sigma / d \varepsilon-\varepsilon$ 曲線と $\sigma-\varepsilon$ 曲 線の交点が $\varepsilon_{\mathrm{m}}$ となることである。この条件は Ludwik 式においても適用される。ここで，Ludwik 式を用いて 計算した $\varepsilon_{\mathrm{m}}$ を $\varepsilon_{\mathrm{mL}}$ とする。さて, この時に重要なのは (4)式より $d \sigma / d \varepsilon-\varepsilon$ 曲線と $\sigma-\varepsilon$ 曲線の交点は，実際の 
応力一ひずみ曲線が描く形状を最大荷重点近傍でいかに 正確に近似できるかにより異なるということである。従 つて，低ひずみ領域で得られた值はこうした検討には使 用できない。なぜならば，高ひずみ領域では動的回復の 影響が強く，応力一ひずみ曲線の形状が変化してしまつ ているからである (Fig. 5, 8 参照)。そこで, Ludwik 式 の近似により，低ひずみ領域からの外插からはずれて下 回る高ひずみ領域が最大荷重点に至るまで近似できない かと試みたのが Fig. 9 である。図から分かるように高 ひずみ領域においても，低ひずみ領域とは別の近似曲線 で実際の応力一ひずみ曲線がよく近似できる。

このような結果は他の合金においても同様であり，本 実験に用いた合金では最大荷重点までの応力一ひずみ曲 線を 2 本の近似曲線によりほぼ近似できた。この高ひず み側の近似曲線を用いて最大荷重点までのひずみ量と $\varepsilon_{\mathrm{mL}}$ との比較を行つたのが Table 3 である。 $\varepsilon_{\mathrm{mL}}$ の值の 方がいずれの合金においても実測值よりも高いが，比較 的に近い值が得られている。この実測值と $\varepsilon_{\mathrm{mL}}$ の值の相 違は本実験で行つた近似がなお若干の誤差を持つている ことを示しており，さらに㛜密な近似を行えば，より正 確に実測值と合うものと推測される。ここで，比較のた めに Ludwik 式で用いたのと同様のひずみ範囲を用いて Hollomon 式による近似を行つた結果を表中に併記して いる。いずれの場合も $\varepsilon_{\mathrm{mL}}$ よりも $n_{H}$ が大きな值をとつ ている。しかし，本結果においても $\varepsilon_{\mathrm{m}}$ が大きくなれば $n_{H}$ も大きくなるという相関関係は持つているようであ る。従つて，先に推測したように本実験に用いた合金の 高ひずみ側ではひずみ領域を限つて近似すると， Hollomon 式によつても Ludwik 式によるよりも精度は 劣るが，実際の応力一ひずみ曲線がある程度近似されう ることが推察される。

\section{4. 結言}

アルミニウム基合金において多用されており，実験的 な加工硬化式の代表的な存在である Hollomon 式の妥当 性を $\mathrm{Al}-\mathrm{Mg}, \mathrm{Al}-\mathrm{Cu}$ および $\mathrm{Al}-\mathrm{Zn}$ 合金の実際の応力一 ひずみ曲線の形状に基づいて再検討したところ, 要約す ると以下のような結論が得られた。

(1) Hollomon 式は実際の金属材料が有する降伏応力 (あるいは比例限) を評価できないという根本的な欠陥 を持ち，このことが，Hollomon 式による近似における 応力とひずみの両詨数プロットに曲率を持たせる原因と なることが実証された。

(2) Hollomon式の欠陷を修正した形を持つ Ludwik
式を用いると，動的回復が激しくなると思われるひずみ 量より小さいひずみ範囲でかなり良く応力一ひずみ曲線 を近似できた。そのひずみ量よりも大きいひずみ範囲で も，ひずみの小さい範囲とは異なる近似線によりほぼ近 似できた。このように応力一ひずみ曲線に 2 本の近似曲 線が必要なことが，従来 Ludwik 式では低ひずみ領域が 良く近似でき，高ひずみ領域では近似が難しいといわれ る理由であろう。

(3) Ludwik 式の高ひずみ領域で近似される曲線を用 いて計算した最大荷重点までのひずみ量は実測值に対し て比較的近い值が得られた。同じひずみ領域を用いて Hollomon 式で近似すると, Ludwik 式から求めた值よ りもいずれも $n_{H}$ の值が高かつた。

\section{参 考 文 献}

1) J. H. Hollomon: Trans. AIME, 162 (1945), 268.

2) D. C. Ludwigson: Met. Trans., 2 (1971), 2825.

3) B. A. Riggs: Sheet Metal Industries., 50 (1973), 620.

4）宮川，朴，西村：塑性と加工，4 (1963), 483.

5) W. Heye, H. P. Scattler: Materialprüf, 13 (1971), 273.

6）金森他：軽金属，27(1977), 348 .

7）西村他：A1100 板の成形性, 研究委員会金属成形 部会編, 軽金属学会, (1982).

8) E. S. Kayali, A. Plumtree: Met. Trans. A, 13A (1982), 1033.

9) P. Ludwik: Elemente der Technologischen Mechanik, Springer-Verlag, Berlin, (1909).

10) H. W. Swift: J. Mech. Phys. Solids, 1 (1952), 1.

11) E. Voce: J. Inst. Metals, 74 (1948), 537.

12) G. Jagaden, J. Voinchet, P. Rocquet: Sheet Metal Industies, 45 (1968), 789.

13) R. G. Davies: Met. Trans. A, 10A (1979), 113.

14）加藤：金属塑性加工学, 加藤著, 丸善, (1980), 36.

15) L. Ratke, P. lan Welch: Z. Metallkde., 74 (1983), 226.

16） B. Jaoul：金属の塑性，諸住，舟久保訳，幸田監 修，丸善，(1969)，395.

17) G. Pysz, M. Krumnacker, G. Naether: Neue Hütte, 23 (1978), 136.

18) D. J. Loyd, D. Kenny: Met. Trans. A, 13A (1982), 1445 .

19）丸川：転位論一その金属学への応用一, 日本金属 学会編, 丸善, (1971), 65

20) C. Adams, J. B. Beese: J. Eng. Mater. Tech. (Trans. ASME), 96 (1974), 123.

21) G. H. Crussard, B. Jaoul: Rev. Metallurgie, 47 (1950), 589.

22) B. Jaoul: J. Mech. Phys. Solids, 5 (1957), 95 